\title{
Tetracycline: production, waste treatment and environmental impact assessment
}

\author{
Alexandre Augusto Borghi, Mauri Sergio Alves Palma* \\ Department of Biochemical and Pharmaceutical Technology, School of Pharmaceutical Sciences, \\ University of São Paulo, São Paulo-SP, Brazil
}

\begin{abstract}
The frequent occurrence of pharmaceuticals in the aquatic environment requires an assessment of their environmental impact and their negative effects in humans. Among the drugs with high harmful potential to the environment are the antibiotics that reach the environment not only, as may be expected, through the effluents from chemical and pharmaceutical industries, but mainly through the sewage and livestock; because around 25 to $75 \%$ of the ingested drugs are excreted in unchanged form after the passage through the Gastro-Intestinal Tract. Tetracycline has high world consumption, representing a human consumption of about $23 \mathrm{~kg}$ /day in Brazil in 2007. At the moment, researches are being made to develop new tetracycline that incorporate heavy metals $(\mathrm{Hg}, \mathrm{Cd}, \mathrm{Re}, \mathrm{Pt}, \mathrm{Pd})$ to their structures in order to increase their bactericidal effect. The conventional wastewater treatment plants are not able to degrade complex organic molecules to reduce their toxicity and improve their biodegradability. For this reason new technologies, i.e., the advanced oxidation processes, are being developed to handle this demand. The objectives of this study are to review the literature on the processes of obtaining tetracycline, presenting its waste treatment methods and evaluation of their environmental impact.
\end{abstract}

Uniterms: Tetracyclines/production. Tetracyclines/waste/tratament. Tetracyclines/waste/environmental impact. Environmental contamination. Domestic sewage/treatment. Industrial wastewater/treatment. Advanced oxidation processes/wastewater treatment.

A ocorrência frequente de fármacos no meio aquático exige a avaliação do seu impacto ambiental e seus efeitos negativos em seres humanos. Dentre os fármacos com maior potencial de impacto ambiental estão os antibióticos, que chegam ao meio ambiente através dos efluentes de indústrias químico-farmacêuticas e, principalmente, através de esgotos domésticos e criação de animais, visto que $25 \%$ a $75 \%$ dos fármacos são excretados em forma inalterada após passagem pelo Trato Gastrointestinal. Parcela significativa do consumo mundial dos antibióticos corresponde à classe das tetraciclinas, representando consumo humano de $23 \mathrm{~kg} /$ dia no Brasil, em 2007. Atualmente, há pesquisas de novas tetraciclinas que incorporam metais pesados ( $\mathrm{Hg}, \mathrm{Cd}, \mathrm{Re}, \mathrm{Pt}, \mathrm{Pd}$ ) às suas estruturas com o intuito de aumentar suas atividades bactericidas. As estações de tratamento de águas residuais convencionais não são capazes de degradar moléculas orgânicas complexas, diminuir a sua toxicidade e melhorar a sua biodegradabilidade. Por esta razão, as novas tecnologias, como, por exemplo, os processos oxidativos avançados, estão sendo desenvolvidos para lidar com esta demanda. Os objetivos deste trabalho são fazer uma revisão da literatura sobre os processos de obtenção de tetraciclinas, apresentar métodos de tratamento de seus resíduos e avaliar o seu impacto ambiental.

Unitermos: Tetraciclinas/produção. Tetraciclinas/resíduos/tratamento. Tetraciclinas/resíduos/impacto ambiental. Contaminação ambiental. Esgoto doméstico/tratamento. Efluentes industriais/tratamento. Processos oxidativos avançados/tratamento de águas residuais. 


\section{INTRODUCTION}

The main route of entry of pharmaceuticals in the environment is the release of domestic sewage, treated or untreated, into watercourses. However, we also must consider the effluents of pharmaceutical and chemical-pharmaceutical industries, rural effluents, and the presence of drugs in animal manure used for soil fertilization and improper disposal of expired products or unwanted drugs (Aga, 2008).

The world consumption of antibiotics has risen drastically in the last decade, also increasing the excretion of their metabolites in their original form. Most antibiotics are poorly metabolized by humans and animals after ingestion, providing that a fraction of antibiotics from $25 \%$ to $75 \%$ may leave the bodies in an unaltered form after consumption (Khan, Ongerth, 2004; Watkinson et al., 2009; Rivas et al., 2011).

Tetracyclines, according Gu and Karthikeyan (2005), are the second group of antibiotics produced and more consumed worldwide.

They are considered to be safe drugs and have many favorable properties such as broad spectrum of activity, low toxicity, low cost, and it can, in most cases, be administered orally (Jeong et al., 2010). The most common side effects are nausea, vomiting and diarrhea. A unique constraint is for pregnant women and children during growth due to its deposition in bones and teeth calcification. Less common effects are induced photosensitivity, urticaria, headache, abdominal pain, hypertension, fever, mild leukopenia, anemia and thrombocytopenia. Patients who take insulin must be monitored, since tetracyclines may increase the persistence of insulin in the body, requiring more closely blood glucose levels monitoring in that patients (Zhanel et al., 2004).

Besides the use in humans, the tetracyclines are used in animal therapy to treat infections and promote growth. Oxytetracycline and chlortetracycline are two of the ten antimicrobials authorized in the United States as growth promoters for cattle (Jeong et al., 2010).

Tetracyclines are the third most consumed antibiotic, after penicillin and quinolones, and due to their indiscriminate use it has been detected an increasing number of bacteria resilient to tetracyclines (Pereira-Maia et al., 2010).

The phenomenon of resistance is indeed nowadays a great concern as there are strains resilient to almost all currently known agents (Rocha et al., 2011).

In this work is presented the processes of obtaining tetracycline, the treatment of their waste and the environmental impact assessment of waste containing tetracycline.

\section{HISTORIC OF TETRACYCLINE}

The discovery of the first member of the family of tetracyclines was in 1945 by Benjamin Duggar, and received the name of aureomycin (chlortetracycline), which is a product of natural fermentation of the bacteria Streptomyces aureofaciens, naturally present in the soil. Two years later, a second isolated tetracycline, terramycin called (oxytetracycline) was synthesized by the bacteria Streptomyces rimosus. In 1953, there was obtained the tetracycline molecule which has the simplest structure of this antibiotic family maintaining its functions. It was obtained through a biological process followed by a chemical process, which consisted in obtaining a precursor molecule by fermentation, followed by a chemical reaction for introducing of functional groups in the precursor molecule. It was observed that the basic structure of two antibiotics, aureomycin and terramycin, were the same, and the generic name tetracycline was suggested. After that many studies began to search for new tetracyclines (PereiraMaia et al., 2010; Sociedade Brasileira de Pediatria, 2012).

The three tetracycline antibiotics (tetracycline, oxytetracycline and chlortetracycline) were the basis for obtaining new derivatives in order to obtain less toxic drugs with better therapeutic use. Several byproducts were synthesized such as demeclocycline, rolitetracycline and the methacycline, which are considered first generation tetracyclines. An inconvenient of these antibiotics was the short time they could persist in the body, and it was overcome by the second generation tetracycline, doxycycline and minocycline (Sociedade Brasileira de Pediatria, 2012).

Thus, from 1950 to 1970 , several members of the tetracycline family had been obtained, as natural or semisynthetic products, and in this same period, tetracyclines remained among the most commonly used antibiotics in the United States (Pereira-Maia et al., 2010).

\section{PROPERTIES OF THE TETRACYCLINES}

Tetracyclines constitute a large group of broad spectrum antibiotics obtained by fermentation of a specific bacteria Streptomyces aureofaciens e Streptomyces rimosus (tetracycline, chlortetracycline and oxytetracycline), semisynthetic processes (demeclocycline, rolitetracycline and methacycline) or synthetic (doxycycline and minocycline), with low molecular weight, good oral absorption and efficient hepatic excretion (Sociedade Brasileira de Pediatria, 2012).

It acts as inhibitor of protein synthesis by preventing the binding of aminoacyl-tRNA to the A site of the 
bacterial ribosome (Hasan et al., 1985).

All tetracyclines have the same spectrum and mechanism of action, adverse effects and similar tolerances by resilient organisms. However, they present some differences regarding pharmacokinetics (Sociedade Brasileira de Pediatria, 2012).

According to Pereira-Maia et al. (2010) the absolute configuration of the natural carbon atom C-4 is an essential requirement for the pharmacological action of these compounds. The presence of the amide grouping at C-2 was also considered as a structural feature required for the biological action of tetracyclines. Another important observation related to increased enzyme inhibitory power was the absence of methyl groups and hydroxyl at position C-6. All these features are shown in Figure 1.

The pharmacokinetics for most tetracyclines is generally oral or parenteral, and is mainly absorbed in the stomach and upper small intestine (Pereira-Maia et al., 2010). Tetracyclines have low metabolic rate, less than $20 \%$ of the administered dose, i.e. more than $80 \%$ are eliminated mainly as unchanged through the intestinal tract (Regitano, Leal, 2010). Despite the similarity of metabolism of various representatives of the tetracycline family one of the main differences among the tetracyclines is their half-life in the body, which is presented below (Pereira-Maia et al., 2010; Regitano, Leal, 2010):

- doxycycline and minocycline are well absorbed by the body. They are long-acting drugs with long half-live greater than $15 \mathrm{~h}$.

- demeclocycline action is a drug with an average half-life of $12 \mathrm{~h}$.

- chlortetracycline, oxytetracycline and tetracycline are characterized by a poor absorption ( 25 to $30 \%$ ), which is even smaller after food ingestion. They are considered active drugs with short half-life of 6 to $9 \mathrm{~h}$.

Tetracyclines in the blood plasma are transported as calcium complex that once inside the cells of the bacteria, forms a complex with magnesium, which binds to the ribosome. In this regard, it is known that the binding of the ribosome complex magnesium inhibits protein synthesis by triggering the bacteriostatic effect (Rocha et al., 2011), which do not kill the microorganism, but acts as preventing bacterial multiplication and are eliminated by the defense system of the patient (Mathers et al., 2011).

In aqueous solutions, depending on the $\mathrm{pH}$, three different groups within the molecule may undergo protonation or deprotonation (dimethylammonium, tricarbonylamide and phenolic diketone) (Zhao et al., 2011a). Generally, tetracyclines, behave positive ( $\mathrm{pH}$ $<3.3)$, neutral $(3.3<\mathrm{pH}<7.68)$ or negative $(\mathrm{pH}>7.68)$ (Zhao et al., 2011b). The tetracyclines are strong chelating agents and $\mathrm{pH}$ dependent, and they have their antibacterial activity and pharmacokinetics decreased when associated with foods rich in calcium, iron, magnesium and other minerals or antacids such as sodium bicarbonate, which increase the $\mathrm{pH}$ in the stomach. Doxycycline has been an exception, because the ingestion of substances that increase gastric $\mathrm{pH}$ does not decrease its absorption (Pereira-Maia et al., 2010).

\section{APPLICATION}

Tetracyclines in normal use concentrations are

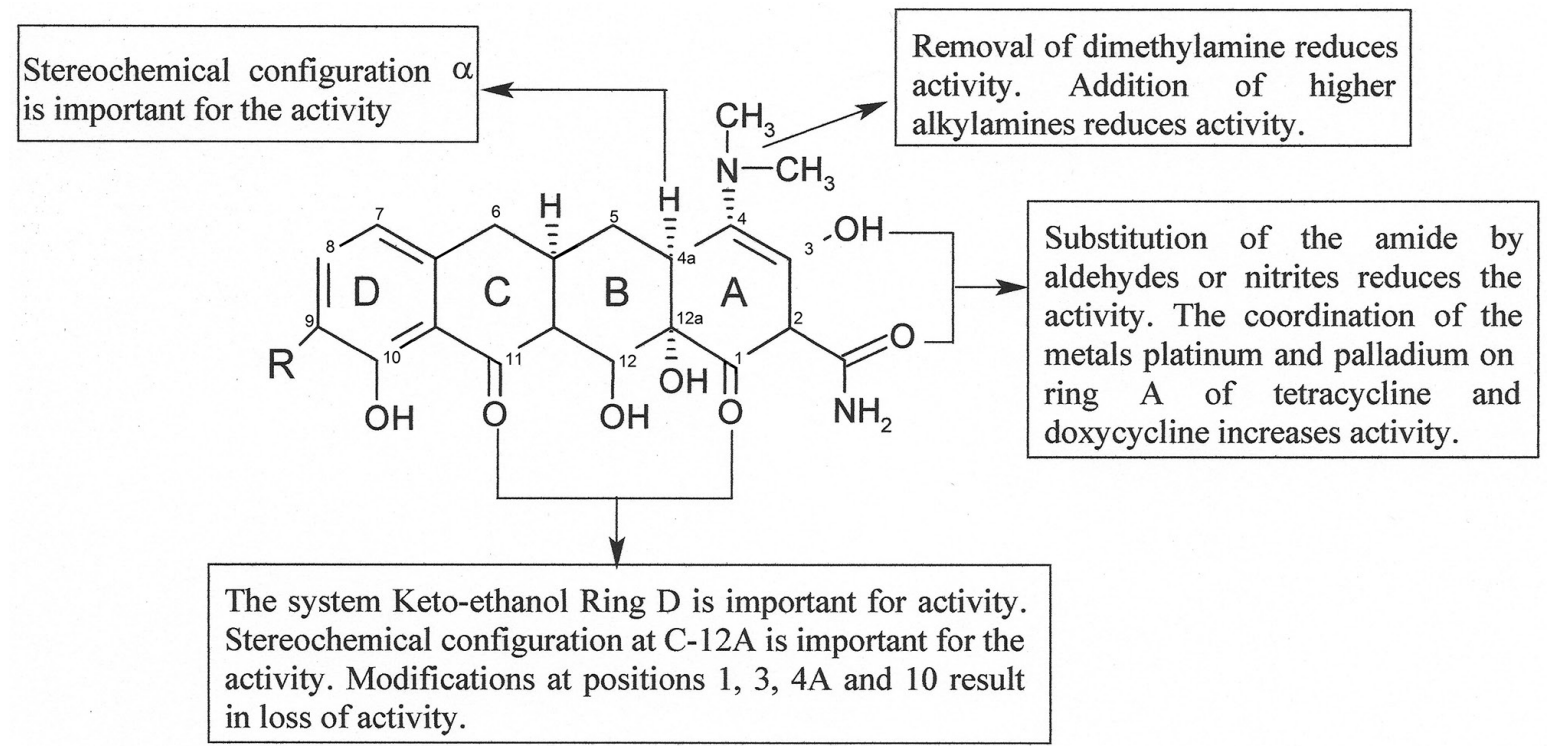

FIGURE 1 - Relationship between the structure and activity of the molecule of tetracycline (Adapted from Pereira-Maia et al., 2010). 
bacteriostatic, helping the inhibition of protein synthesis by binding to the $30 \mathrm{~S}$ fraction of the bacterial chromosome by preventing the attachment of tRNA, interfering with the supply and connecting the amino acids forming proteins. In higher concentrations they can exercise bactericidal effect.

In general, the more lipophilic molecules are more active than the hydrophilic due to their interaction with lipoprotein in biological membranes. Tetracycline have the ability to cross the cell membrane by passive diffusion process and by active transport due to its good diffusion inside the cells and therefore exhibit excellent antibiotic activity against intracellular bacteria (Zhanel et al., 2004; Sociedade Brasileira de Pediatria, 2012).

They are usually indicated for infections whose agents are Rickettsia, Chlamydia, Mycoplasma and Borrelia, Campylobacter, Ureaplasma urealyticum and Legionella. They are effective in treating spotted fever, epidemic typhus, Q fever and other rickettsial diseases. They also act on psittacosis, Lymphogranuloma venereum caused by the chlamydia; in atypical pneumonias caused by Mycoplasma pneumoniae. They have action in the treatment of brucellosis, tularemia, bartonellosis, actinomycosis, recurrent fevers, cholera. They are indicated for penicillin-allergic patients and patients with gonorrhea. They can be used for infections caused by group A Streptococcus, Staphylococcus, Pneumococcus, Gram-positive and Gram-negative and espiroquetoses and as second choice in the treatment of Plasmodium falciparum malaria, amebiasis by the Entamoeba histolytica, peptic ulcers caused by Helicobacter pylori and the treatment and prevention of bacteria used as biological weapons in terrorism such as anthrax (Cox, Popken, 2010; Pereira-Maia et al., 2010; Mathers et al., 2011; Sociedade Brasileira de Pediatria, 2012).

In relation to the pharmacological properties of these compounds, they possess a number of non-antibiotic properties and several studies have been conducted to use tetracyclines in the treatment of non-infectious diseases such as rheumatoid arthritis and cancer (Regitano, Leal, 2010; Mathers et al., 2011).

Mathers et al. (2011) presented several studies on various mechanisms for non-antibiotic tetracyclines, such as the control of inflammation, inhibition of tumor progression, bone resorption, angiogenesis and stroke due to inhibition of protein kinase $\mathrm{C}$ and metalloproteinases, the inhibition of nitric oxide synthase, leading to nonproduction of nitric oxide, which is responsible for the classic inflammatory symptoms in osteoarthritis, rheumatoid arthritis, systemic lupus erythematosus, ulcerative colitis and Crohn's disease, exerting effects "chondro protective" prophylactic effects of treatment of acne, wound healing and inhibition of collagen gel contraction by myofibroblasts.

The main advantage of the antineoplasic action of tetracyclines (especially doxycycline) is compared to greater tolerance with increasing dose of the drug, allowing the synergistic treatment with drugs such as cisplatin, currently used in lower doses, while maintaining the efficacy of the treatment (Pereira-Maia et al., 2010).

\section{CONSUMPTION IN LATIN AMERICA}

Wirtz et al. (2010) used the studies presented by the World Health Organization (WHO) in the period 1997 to 2007 to evaluate in the consumption of antibiotics in eight Latin American countries. The results reported by WHO were based on national sales of antibiotics for the retail (direct sales in private pharmacies and indirect sales in private clinics and hospitals), not providing information of antibiotics purchased by the public sector (government contractors).

Figure 2 shows the daily consumption of various antibiotics consumed in many Latin American countries in 2007.

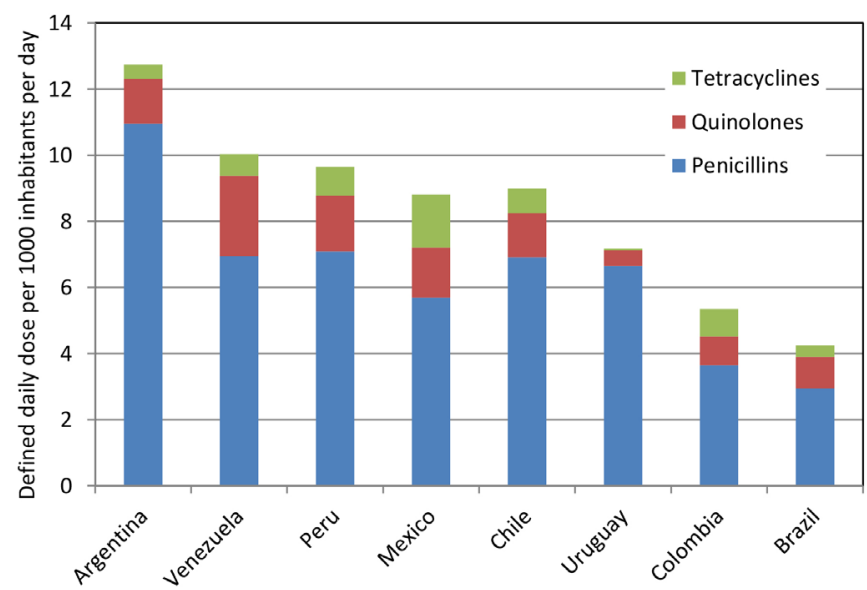

FIGURE 2 - Use of antibiotics in eight Latin American countries, by therapeutic class in the year 2007 (Adapted from Wirtz et al., 2010).

According to data provided by Wirtz et al. (2010) and Brazilian population estimates for the year 2007, we can say that tetracyclines are the third most consumed antibiotics in Brazil, after penicillin and quinolones, representing $23 \mathrm{~kg}$ /day for human consumption.

Little information about the dispensing of antibiotics is offered in existing bibliographies, especially in developing countries, where control is still very deficient 
(Díaz-Cruz and Barceló, 2007). However, it is estimated that more than $70 \%$ of such compounds are antibiotic agents (Thiele-Bruhn, 2003).

In a more recent estimate (Kools et al., 2008) about 4.6 million kilos of antibiotics were used for animal production in the countries of the European community, and tetracyclines, the $\beta$-lactams and cephalosporins were the most consumed products.

In Brazil, in general, there are no statistics about the amount of antibiotics sold for animal production. The Ministry of Health of Paraná, in 2005, conducted a qualitative study on the marketing of veterinary medicines in broilers, where groups of preventive medications most frequently cited were fluoroquinolones (34\%), ionophores $(20 \%)$, macrolides $(10 \%)$, quinolones, tetracyclines $(6 \%)$, sulfonamides $(4 \%)$, lincosamides $(3 \%)$. The most cited therapeutics already cited were ionophores (25\%), fluoroquinolones (19\%), sulfonamides (14\%), tetracycline (11\%), $\beta$-lactams (7\%), macrolides $(5 \%)$ and aminoglycosides (4\%). This same survey also found some irregularities such as the use of tetracyclines, tiamulin, ciprofloxacin, norfloxacin and enrofloxacin as growth promoters, which are prohibited by the Ministério da Agricultura, Pecuária e Abastecimento (MAPA) (Regitano and Leal, 2010).
According to Pereira et al. (2012), it is estimated that in the year 2009, the sale of antibiotics for veterinary use in Brazil with the most varied purposes (therapeutic, preventive or growth promoter) was about US\$ 379 million.

\section{BACTERIAL RESISTANCE MECHANISMS}

In Table I are shown some results of the in vitro activity of four tetracyclines for Gram-negative and Grampositive bacteria with relevance in medical clinic. Table I shows the minimum drug concentration required to inhibit $90 \%$ of growth of the bacteria $\left(\mathrm{MIC}_{90}\right)$ (Pereira-Maia et al., 2010).

Interestingly, a study by Mathers et al. (2011) showed that only $20 \%$ of the Escherichia coli present in human intestine was resistant to tetracycline before the treatment of acne. In the same study was shown that resistance was increased to $96 \%$ after 10 weeks of use of the antibiotic (500-1000 $\mathrm{mg} /$ day).

Two mechanisms of clinical significance are primarily responsible for bacterial resistance to tetracyclines:

- $\quad$ Removing active antibiotics from the cell through the mechanism known as efflux pumps, causing

TABLE I - In vitro activity of tetracyclines in selected organisms (Pereira-Maia et al., 2010)

\begin{tabular}{lcccc}
\hline \multirow{2}{*}{ Bacteria } & Tetracycline & Doxycycline & Minocycline & Tigecycline \\
\cline { 2 - 5 } & \multicolumn{3}{c}{$\mathrm{MIC}_{90}(\mathrm{mg} / \mathrm{L})$} \\
Gram-positive & 1 & 0.5 & 0.12 & 0.5 \\
Staphylococcus aureus (MS) & 32 & 2 & 2 & 0.5 \\
Staphylococcus aureus (MR) & 32 & 8 & 8 & 0.125 \\
Streptococcus pneumoniae (PS) & 64 & 8 & 16 & 0.125 \\
Streptococcus pneumoniae (PR) & 128 & 16 & 32 & 0.25 \\
Enteroccocus faecalis & 64 & 16 & 16 & 0.25 \\
Enteroccocus faecium & & & & 1 \\
Gram-negative & 0.5 & 3.1 & 0.25 & 2 \\
Haemophilus influenza & 1 & $\mathrm{ND}$ & 1 & 1 \\
Haemophilus influenza (BLP) & 4 & $\mathrm{ND}$ & 4 & 1 \\
Klebsiella pneumoniae & $>32$ & 2 & 32 & 0.5 \\
Neisseria gonorrhoeae (PS, PR) & $>8$ & $\mathrm{ND}$ & 8 & 0.125 \\
Escherichia coli & $\mathrm{ND}$ & 0.25 & $\mathrm{ND}$ \\
Atypical organisms & $1-8$ & 4 & 4 & 0.25 \\
Chlamydia pneumoniae & 1 & 1.6 & 1 & $\mathrm{ND}$ \\
Legionella pneumophila & & & & \\
Mycoplasma pneumoniae & & & & \\
\hline
\end{tabular}

$\mathrm{ND}=$ not determined 
the antibiotic to be quickly pumped out of the cell. In case the tetracycline efflux occurs through trans membrane proteins (Tet A) exporting the molecule complexed with $\mathrm{Mg}^{2+},[\mathrm{MgTc}]^{+}$out of the cell, leading to a lower concentration of drug within the bacterial cells (Depizzol, 2006; Pereira-Maia et al., 2010).

- The ribosomal protection through cytoplasmic proteins that protect the ribosome from the action of tetracyclines (Pereira-Maia et al., 2010).

Both mechanisms enable protein synthesis proceed normally. Figure 3 outlines the mechanism of bacterial resistance to efflux mechanism.

\section{COORDINATION OF METALS}

Recently, several research groups have shown that antibiotics containing metal complexes are often more active than the parent compound. The coordination platinum (II) to tetracycline and doxycycline through the ring A, shown in Figure 1, results in active compounds against bacterial strains resistant to tetracycline and other antibiotics (Pereira-Maia et al., 2010; Rocha et al., 2011).

Some metal complexes are found in several articles presented in the work by Pereira-Maia et al. (2010) and are shown in Table II.

The palladium complex coordinated to tetracycline is sixteen times more potent than the free drug. The coordination of palladium to doxycycline also increases the activity on resistant strains of bacteria, the complex

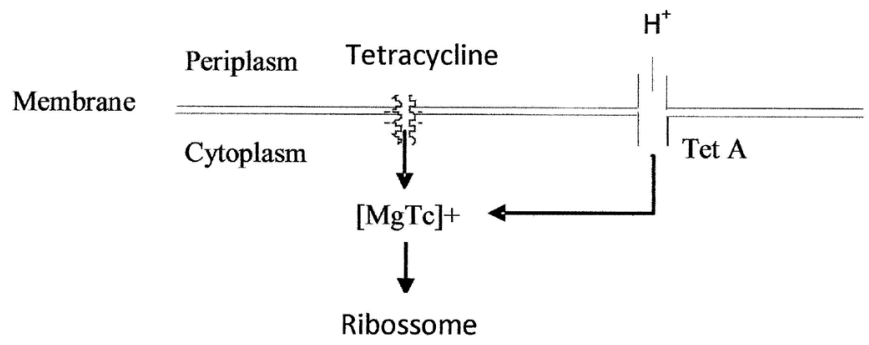

FIGURE 3 - Schematic diagram representing the efflux mechanism of bacterial resistance (Adapted from Pereira-Maia et al., 2010).

being two times more potent than the free drug (Rocha et al., 2011). Table III shows the values of concentration of each compound required to inhibit $50 \%$ of cell growth.

The coordination of antibiotic metal ions has been used not only as a mechanism for reversing resistance, but also as a strategy for developing new drugs, particularly those with activity in the treatment of tumors, studies for directing a new set of substances similar as the Chemically Modified Tetracyclines known as CMTs. The removal of the dimethylamino group in $\mathrm{C} 11$ position (Figure 1) eliminates the antibacterial action and potentiates side effects. The chemotherapeutic action occurs through inhibition of enzymes known as MMP (matrix metalloprotease), focusing in prevention of angiogenesis and metastasis (Pereira-Maia et al., 2010; Rocha et al., 2011).

Despite several trials in developing these modified molecules, their introduction in the market should be carefully evaluated because the bioaccumulation of a

TABLE II - Metal complexes as binders using tetracycline (Pereira-Maia et al., 2010)

\begin{tabular}{|c|c|c|c|c|}
\hline Reagents and stoichiometry & Solvent & $\mathrm{pH}$ & Product obtained & Coordination site \\
\hline $\mathrm{LnCl}_{3}+\mathrm{TC} \cdot \mathrm{HCl}$ & $\mathrm{MeOH}$ & 7.0 & {$\left[\mathrm{Ln}(\mathrm{TC}) \mathrm{Cl}_{3}\right] \cdot 2 \mathrm{H}_{2} \mathrm{O}$} & $\mathrm{O}_{6}, \mathrm{O}_{7}$ e $\mathrm{O}_{15}$ \\
\hline $\mathrm{NiCl}_{2} \cdot 6 \mathrm{H}_{2} \mathrm{O}+2.1 \mathrm{TC} . \mathrm{HCl}$ & $\mathrm{MeOH}$ & 7.5 & {$\left[\mathrm{Ni}(\mathrm{TC})_{2}\left(\mathrm{H}_{2} \mathrm{O}\right)_{2}\right]$} & Oxygens - ring A \\
\hline $\mathrm{CoCl}_{2} \cdot 6 \mathrm{H}_{2} \mathrm{O}+2.2 \mathrm{ATC} . \mathrm{HCl}$ & $\mathrm{MeOH}$ & 8.0 & {$\left[\mathrm{Co}(\mathrm{ATC})_{2}\left(\mathrm{H}_{2} \mathrm{O}\right)_{2}\right]$} & Oxygens - ring A \\
\hline $\mathrm{K}_{2} \mathrm{PdCl}_{4}+\mathrm{TC} . \mathrm{HCl}$ & $\mathrm{H}_{2} \mathrm{O}$ & NF & {$\left[\mathrm{Pd}(\mathrm{TC}) \mathrm{Cl}_{2}\right] \cdot 2 \mathrm{H}_{2} \mathrm{O}$} & $\mathrm{O}_{12} \mathrm{e} \mathrm{O}_{\text {amide }}$ \\
\hline $\mathrm{K}_{2} \mathrm{PtCl}_{4}+\mathrm{TC} \cdot \mathrm{HCl}$ & $\mathrm{H}_{2} \mathrm{O}$ & NF & {$\left[\mathrm{Pt}(\mathrm{TC}) \mathrm{Cl}_{2}\right]$} & $\mathrm{O}_{12} \mathrm{e} \mathrm{O}_{\text {amide }}$ \\
\hline$* \mathrm{~K}_{2} \mathrm{PtCl}_{4}+4.1 \mathrm{TC}$ & Acetic acid & NF & {$\left[\mathrm{Pt}(\mathrm{ATC}) \mathrm{Cl}_{2}\right]$} & Ring A \\
\hline $\mathrm{K}_{2} \mathrm{PtCl}_{4}+\mathrm{DOX} . \mathrm{HCl}$ & $\mathrm{H}_{2} \mathrm{O}$ & NF & {$\left[\mathrm{Pt}(\mathrm{DOX}) \mathrm{Cl}_{2}\right] \cdot 2 \mathrm{H}_{2} \mathrm{O}$} & $\mathrm{O}_{12} \mathrm{e} \mathrm{O}_{\text {amide }}$ \\
\hline$* \mathrm{Re}(\mathrm{CO}) \mathrm{Cl}+\mathrm{OTC} . \mathrm{HCl}$ & Toluen & $\mathrm{NF}$ & {$\left[\mathrm{Re}(\mathrm{OTC})(\mathrm{CO})_{3} \mathrm{Cl}\right]$} & $\mathrm{O}_{6} \mathrm{e} \mathrm{O}_{7}$ \\
\hline$* * 1.4 \mathrm{Cu}\left(\mathrm{ClO}_{4}\right)_{2}+2.5 \mathrm{TC}$ & EtOH- Teof & $\mathrm{NF}$ & {$\left[\mathrm{Cu}(\mathrm{TC})_{2}\left(\mathrm{ClO}_{4}\right)_{2}\right]$} & $\mathrm{O}_{12} \mathrm{e} \mathrm{O}_{\text {amide }}$ \\
\hline$* * 1.4 \mathrm{Fe}\left(\mathrm{ClO}_{4}\right)_{3}+2.5 \mathrm{TC}$ & EtOH- Teof & NF & {$\left[\mathrm{Fe}(\mathrm{TC})_{2}\left(\mathrm{ClO}_{4}\right)_{3}\right]$} & $\mathrm{O}_{12} \mathrm{e}_{\text {amide }}$ \\
\hline$* * * \mathrm{HgCl}_{2}+\mathrm{OTC}$ & $\mathrm{H}_{2} \mathrm{O}-\mathrm{MeOH}$ & NF & {$\left[\mathrm{Hg}(\mathrm{OTC}) \mathrm{Cl}_{2}\right] \cdot 2 \mathrm{H}_{2} \mathrm{O}$} & $\mathrm{O}_{12} \mathrm{e} \mathrm{O}_{\text {amide }}$ \\
\hline
\end{tabular}

$*$ Reaction made at $70^{\circ} \mathrm{C}$. ** Reaction made between $40-50{ }^{\circ} \mathrm{C}$. $* * *$ Crystals obtained at $8{ }^{\circ} \mathrm{C}$. Ln $=$ Lanthanides in general, Teof $=$ Triethyl orthoformate, $\mathrm{NF}=\mathrm{pH}$ not fixed. The coordination sites are shown in Figure 1. 
TABLE III - $\mathrm{IC}_{50}$ values for complexes of palladium $(\mathrm{Pd})$ and platinum complexes (Pt) (Rocha et al., 2011)

\begin{tabular}{lc}
\hline Compound & $\mathrm{IC}_{50}(\mu \mathrm{M})$ \\
\hline Doxycycline & 17.7 \\
Tetracycline & 52.37 \\
Complex of $\mathrm{Pd}^{2+}$ with tetracycline & 34.54 \\
Complex of $\mathrm{Pd}^{2+}$ with doxycycline & 14.14 \\
Complex of $\mathrm{Pt}^{2+}$ with doxycycline & 6.3 \\
Complex of $\mathrm{Pt}^{2+}$ with tetracycline & 9.39 \\
\hline
\end{tabular}

$\mathrm{IC}=$ inhibitory concentration

metal ion can cause severe side effects. Therefore, their pharmacological and physiological actions must be studied in vivo, in animals, before their use in human clinic tests (Rocha et al., 2011).

\section{OCCURRENCE IN THE ENVIRONMENT}

Residues of antibiotics, including tetracyclines from Wastewater Treatment Plants (WWTPs) of urban and agricultural effluents are frequently detected in surface water, groundwater, soils and sediments (Zhao et al., 2011b).

The antibiotics oxytetracycline and doxycycline are commonly detected in aquatic environment and WWTPs effluents (Yuan et al., 2011). Generally, they are present in relatively low concentrations (ng or mg per L), below the threshold levels to show the effects of medicinal treatment on bacterial populations and other exposed species (Boxall et al., 2003; Zhao et al., 2011b).

The existing literature is restricted almost entirely to works developed in environment temperate conditions (Regitano, Leal, 2010).

The use of animal excreta and sewage sludge as fertilizers are major routes of spread of these compounds in the environment (Regitano and Leal, 2010). The final disposition of these effluents in rivers and agricultural use of sewage sludge or organic fertilizers are an important source of environmental exposure to wide range of pharmaceuticals for humans and animals (Kim et al., 2007).

The environmental destiny and behavior presented by drugs contained in several sources are influenced by a variety of factors, including the physicochemical properties of the molecule, properties of the soil and of the environmental conditions (Kemper, 2008). Tetracyclines have low potential for mobility in soil due to its high potential for adsorption $\left(K_{D}=70-5000 \mathrm{~L} / \mathrm{kg}\right)$
(Tolls, 2001; Regitano, Leal, 2010). Typical examples of tetracyclines in the environment are the chlortetracycline and oxytetracycline, which have a high potential for dissemination in the environment due to their use in animal intensive farming and aquaculture, where the administration is primarily topically or orally. The metabolism in the animal organism is usually low (Boxall et al., 2003).

Antibiotics with half-life $\left(t_{1 / 2}\right)$ of permanence in environment more than 60 days are considered very persistent, while those compounds exhibiting $t_{1 / 2}$ longer than 14 days may present environmental problems due to leaching (Regitano and Leal, 2010).

Several studies on the adsorption of tetracyclines in relation to the adsorbent matrix components are given below.

Sassman and Lee (2005) investigated the main mechanism involved in cation exchange and adsorption potential. They observed that $\mathrm{pH}$ influenced the cation exchange capacity of the predominant minerals in the soil matrix.

Thiele-Bruhn (2003) observed that the highest potential adsorption occurred in the presence of cations of higher valency $\left(\mathrm{Ca}^{2+}\right.$ instead of $\mathrm{Na}^{+}$, for example) due to complex formation between the tetracycline and multivalent cations.

Zhao et al. (2011a,b) studied five cations $\left(\mathrm{Li}^{+}, \mathrm{Na}^{+}\right.$, $\mathrm{K}^{+}, \mathrm{Ca}^{2+}$ and $\mathrm{Mg}^{2+}$ ) with concentration of $0.01 \mathrm{M}$ and observed that they exhibited little effect on the adsorption of tetracycline in the $\mathrm{pH}$ range between 3 and 10. Cations of heavy metals such as $\mathrm{Cu}^{2+}$ and soil organic matter (humic acid) exhibited a high effect on the mobility of tetracyclines in the soil, affecting their concentration and toxicity to organisms.

$\mathrm{Gu}$ and Karthikeyan (2005) investigated the interaction of tetracycline with iron oxide and hydrated aluminum oxide. Spectroscopic analysis showed that carbonyl groups tricarbonylamide may be responsible for the adsorption on minerals in clay soil.

Hellweger et al. (2011) claimed that environmental concentrations of tetracycline in surface waters are usually less than $0.11 \mathrm{mg} / \mathrm{L}$, although higher values of up to $6.8 \mathrm{mg} / \mathrm{L}$ have been observed. The MIC values are approximately $3.000 \mathrm{mg} / \mathrm{L}$ for clinical pathogens and $2000 \mathrm{mg} / \mathrm{L}$ for isolates from environmental bacteria. The concentration truly dissolved can be estimated from data equilibrium between phases presented in their work, involving a variety of mechanisms (e.g. cation exchange).

Table IV presents the results of occurrence of tetracycline in the environment. 
TABLE IV - Environmental concentration of antibiotics of the tetracycline family

\begin{tabular}{lccc}
\hline Antibiotic & Mean concentration $(\mu \mathrm{g} / \mathrm{L})$ & Matrix & Country \\
\hline $0.15^{(1)}$ & Surface water & USA \\
& $0.42^{(2)}$ & Natural water & USA \\
up to $0.69^{(3)}$ & Surface water & Water & UK \\
Chlortetracycline & $0.9^{(4)}$ & Soil $(0-30 \mathrm{~cm})$ & North Germany \\
& $4.6-7.3(\mu \mathrm{g} / \mathrm{kg})^{(1)}$ & Soil & UK \\
$41.8(\mu \mathrm{g} / \mathrm{kg})^{(4)}$ & Swine manure & Austria \\
\hline up to $46(\mathrm{mg} / \mathrm{kg})^{(1)}$ & Surface water & USA \\
$0.07-1.34^{(1)}$ & Natural water & USA \\
$0.34^{(2)}$ & Surface water & UK \\
up to $0.34^{(3)}$ & Water & UK \\
$0.5^{(4)}$ & Runoff & England \\
$71.7^{(1)}$ & Soil & UK \\
$8.6(\mu \mathrm{g} / \mathrm{kg})^{(4)}$ & Soil & North Germany \\
$27(\mu \mathrm{g} / \mathrm{kg})^{(1)}$ & Swine manure & Austria \\
\hline up to $29(\mathrm{mg} / \mathrm{kg})^{(1)}$ & Natural water & USA \\
up to $0.11^{(3)}$ & Surface water & UK \\
$0.11^{(4)}$ & Water & UK \\
$1.2 \mathrm{a} 4.2^{(2)}$ & Surface water & Germany
\end{tabular}

(1) Regitano and Leal (2010); (2) Bila and Dezotti (2003); ${ }^{(3)}$ Boxall et al. $(2004) ;{ }^{(4)}$ Boxall et al. (2003).

\section{DAMAGES TO THE LOCAL BIOTA}

Actually little is known about the problem of ecotoxicity promoted by prolonged exposure to low doses of antibiotics, as well as the impacts caused by unknown metabolites in the aquatic environment, since they can also exhibit biocide action, as observed for the degradation products enrofloxacin and tetracycline, as it is unclear which organisms are affected and to what degree (Bila and Dezotti, 2003; Sarmah et al., 2006).

Standard studies involving organisms have demonstrated in vitro that the occurrence of environmental parameters does not exhibit acute effect on the test organisms. Wollenberger et al. (2000) evaluated the acute and chronic toxicity of oxytetracycline, tetracycline, sulphadiazine and tylosin in Daphnia magna. Those authors found no toxic effects in environmentally relevant concentrations; however they observed toxic effects caused by the chronic exposition to high concentrations ( 5 to $50 \mathrm{mg} / \mathrm{L}$ ) of oxytetracycline, tetracycline and sulphadiazine.

Kümmerer (2009) evaluated the toxicity of tetracycline, ampicillin, chloramphenicol and streptomycin to the species Vibrio harveyi. They found no toxic effects for long term tests and for concentrations usually found in the environment. However, they observed a reproduction decrease for the same conditions tested before.

Another relevant factor is related to bioaccumulation in organisms, this process is governed mainly by the lipophilic character of the molecule, which can be expressed by the partition coefficient n-octanol-water $\left(K_{o w}\right)$ usually expressed in logarithmic form (Regitano and Leal, 2010).

Kim et al. (2012) verified the influence of tetracycline concentration $(0.1$ to $5.0 \mathrm{mg} / \mathrm{L})$ on the fecundity (time to first reproduction and number of births per female), longevity, morphological structure (size and weight) and growth in four generations of Daphnia magna. Through this study that authors observed that the reproduction and the number of descendants decreases with increasing concentration of tetracycline to each subsequent generation. On the morphological structure observed increased weight and size, probably due to the decreased reproduction due to the targeting of energy for the development of the structure. Organic molecules with values of $\log K_{o w}>4.0$ tend to accumulate in lipid tissues (Curi et al., 2003).

According to Regitano and Leal (2010), with regard to antibiotics, it can be said that: 
- $\quad$ Few of these molecules have $\log K_{o w}>4.0$;

- Many of them behave as weak acids or basis, undergoing ionization in the $\mathrm{pH}$ conditions found in the environment;

- Many antibiotics are readily metabolized to more polar products, as conjugates;

- The concentrations found in the environment are low;

- There are no practical observations suggesting their bioaccumulation in natural conditions.

According to the information submitted, the potential for bioaccumulation of antibiotics in the environment is minimal.

Only when the concentration remains high for a long period of time, there is excessive accumulation and may develop arthropathy, nephropathy, changes in the central nervous system defects in spermatogenesis, mutagenicity and possible photosensitivity in humans (Kummerer et al., 2000; Reyes et al., 2006).

Cumulative effects of chlortetracycline in plant tissue of cabbage, corn and green onions grown in soil fertilized with contaminated manure are reported by Kumar et al. (2005). Concentrations detected in these plants were in the order of 2-17 ng/g.

Boonsaner and Hawker (2012) studied the accumulation of tetracyclines in rice through the diffusion from aqueous solutions to the roots. They observed that the dissemination within the plant tissue is directly related to the hydrophobicity of the molecule. For concentrations of tetracycline of up to $50 \mathrm{mg} / \mathrm{L}$, during 15 days, those authors did not observe dissemination of tetracycline to plant tissue remaining in the roots, and not caused changes in plant development.

Yang et al. (2013) evaluated the influence of tetracycline on the cyanobacteria Microcystis aeruginosa and chlorophycea Selenastrum capricornutum, abundant in aquatic systems, and observed that tetracycline has toxic effect especially on $S$. capricornutum because, in a first contact, inhibited the rate of biomass production of $20-75 \%$ for tetracycline concentrations of $0.2-5.0 \mathrm{mg} / \mathrm{L}$.

The sources of resistance plasmids in bacteria are old, for example in a study of Psychrobacter psychrophilus isolated from a pellet of frozen ground dated 25000-35000 years, found a tetracycline resistance plasmid, consistent with markers found resistance in bacteria of clinical interest current (Petrova et al., 2009).

Resistant bacteria are generated by natural selection, genetic exchange between soil bacteria and those present in the feces of animals or between antibiotic-producing organisms (Pereira et al., 2012). In addition to DNA, the mechanisms of transposition and plasmid transfer, transduction for tetracycline resistance have been found in bacteriophage Salmonella spp. (Zhang and Lejeune, 2007).

The direct introduction of resistant microorganisms, from feces of animals treated with antibiotics, seems to be more important to the strength of the induction due to the presence of antibiotic residues in the environment (Thiele-Bruhn, 2003; Regitano and Leal, 2010). Esiobu et al., (2002) isolated a bacteria from a garden fertilized with dairy cattle, which had a frequency resistance of the order of $70 \%$ to ampicillin, penicillin, tetracycline, streptomycin and vancomycin.

\section{TREATMENT AND DEGRADATION PRO- DUCTS}

When exposed to the environment, antibiotics suffer oxidative degradation. The products resulting from oxidation of tetracyclines may be even more toxic than the parent compound against bacteria commonly found in the environment (Boxall, 2004; Khetan, Collins, 2007).

Photolysis caused by solar irradiation has been considered as one of the most important processes in the degradation of antibiotics in natural aquatic environment (Andreozzi et al., 2003). This natural photolysis is significant for the degradation of the antibiotics mainly due to the presence of dissolved organic matter (DOM) and nitrate in natural aquatic environments, that can influence the photocatalytic reaction (Andreozzi et al., 2003; Zhan et al., 2006).

The photolysis of antibiotics by solar radiation in the environment can occur in two ways (Andreozzi et al., 2003): direct, through the absorption of radiation by the drug molecule; indirectly, through the photosensibilisation of the molecule by natural components, such as nitrate and humic acids, which under solar irradiation can generate strong oxidizing species such as hydroxyl radicals and Singlet oxygen.

Degradation through solar photolysis can be influenced by the concentration of humic acid which absorbs the radiation and prevents the radiation to reach the other organic molecules (e.g. antibiotics). Another factor to be considered is the light incidence that depends on the latitude and season (Andreozzi et al., 2003).

Investigating the removal of several drugs present in urban and rural wastewater, several works have appeared in recent years in scientific publications, demonstrating the relevance of the subject.

In the case of tetracyclines, while passing through WWTPs, chemical modification may occur by hydrolysis, biodegradation or adsorption in the sludge. Some authors 
claim that adsorption should be the main factor in removing antibiotics, which accumulate in the process and are not eliminated (Khan, Ongerth, 2004; Gartiser et al., 2007). Khan and Ongerth (2004) evaluated the half-life of several drugs during the passage of WWTPs in Australia. They determined that doxycycline had halflife of 52 hours in an activated sludge process operating with suspended solids concentration of $2000 \mathrm{mg} / \mathrm{L}$. Those authors determined that $5 \%$ of the drugs were adsorbed onto the sludge and $22 \%$ were biodegraded.

Ghosh et al. (2009) studied five antibiotics (clarithromycin, enrofloxacin, sulfamethoxazole, tetracycline, trimethoprim) to assess their action on the bacteria responsible for oxidation of ammonia and observed that for concentrations lower than $0.05 \mathrm{mg} / \mathrm{L}$ these drugs, individually, had no significant effect on the bacteria.

Jia et al. (2009) studied the oxytetracycline (OTC) and tetracycline (TC) and its degradation products, 4-epitetracycline (ETC), 4-epioxytetracycline (EOTC), isochlortetracycline (ICTC), anhydrotetracycline (ATC) and 4-epianhydrochlortetracycline (EACTC). Those authors evaluated the concentrations present in the influent, effluent and in the river, receiving the treated effluent, in the city of Beijing, China. The results are shown in Table $\mathrm{V}$.

The presence of tetracyclines in effluents from various sources has stimulated many studies of new processes for the treatment of tetracyclines. Several studies address the mechanisms of degradation with various processes and the identification of products resulting from this degradation. However, most of the oxidation processes are based on the generation of hydroxyl radicals (Fatta et al., 2011).

The hydroxyl radical reacts with tetracycline mainly by electrophilic addition, forming organic radicals, but due to the complexity of the molecule, the stability of organic radical formed, the number of hydrogen atoms (positions of attack), the steric effects and the electronegativity of substituents, often radical reaction occurs with the substituent of the molecule and not with the aromatic ring (Pignatello et al., 2006).

Gujarathi et al. (2005) evaluated the use of Myriophyllum aquaticum and Pistia stratiotes for phytoremediation of effluents containing tetracycline and oxytetracycline. They concluded that the antibiotic molecules are degraded by enzymes present in the roots of these plants and observed almost complete degradation until 6 days after insertion of $P$. stratiotes and 15 days with $M$. aquaticum. The concentration of the antibiotics decreased with increasing initial concentration, which suggests that the modifying compound (catalytic enzyme) present in the roots can be in limited concentrations.

Ikehata et al. (2006) studied the photocatalytic degradation of tetracycline by $\mathrm{TiO}_{2}$ and obtained an almost complete conversion of $50 \mathrm{mg} / \mathrm{L}$ tetracycline treatment in two hours and about $90 \%$ of the Total Organic Carbon (TOC) was removed in $6 \mathrm{~h}$.

Reyes et al. (2006) compared the efficiency of the removal of tetracycline in aqueous suspensions of $\mathrm{TiO}_{2}$ irradiated with three different light sources: a UV lamp, natural solar light and a UV-A lamp. No significant degradation observed when the irradiation was performed in the absence of $\mathrm{TiO}_{2}$. It was observed $50 \%$ degradation of the drug in the presence of $0.5 \mathrm{~g} / \mathrm{L}$ of $\mathrm{TiO}_{2}$ in times of 10,20 and 120 minutes for the UV lamp, natural solar light and UV-A lamp, respectively. However, all the residues obtained through the 3 different treatments retained their bactericidal activity.

Jiao et al. (2008) studied the photocatalytic degradation of tetracycline and the toxicity of its degradation products which had molar mass $(\mathrm{m} / \mathrm{z})$ equal to 398 and 413 . The naphthol of the tetracycline ring remained intact during photolysis and toxicity of the compounds of photolysis using $V$. fischeri showed that toxicity increased with irradiation.

TABLE V - Average concentrations of tetracycline and its byproducts detected in STPs and rivers (Jia et al., 2009)

\begin{tabular}{lccc}
\hline Compound & Inffluent $(\mathrm{ng} / \mathrm{L})$ & Effluent $(\mathrm{ng} / \mathrm{L})$ & River $(\mathrm{ng} / \mathrm{L})$ \\
\hline OTC & 72.5 & 3.8 & 2.2 \\
TC & 16.5 & 1.9 & 2.1 \\
ETC & 5.9 & $<$ BLD $^{*}$ & $<$ BLD $^{*}$ \\
EOTC & 8.5 & $<$ BLD $^{*}$ & $<$ BLD $^{*}$ \\
ICTC & 9.5 & 6.8 & $<$ BLD $^{*}$ \\
ATC & 5.7 & $<$ BLD $^{*}$ & $<$ BLD $^{*}$ \\
EACTC & 25.3 & 7.6 & $<$ BLD* $^{*}$ \\
\hline
\end{tabular}

$*<\mathrm{BLD}=$ below limit of detection 
Sunaric et al. (2009) studied the oxidation of doxycycline with hydrogen peroxide using the copper ion as catalyst. Those authors compare the results of the residual concentration of drug obtained by spectrophotometry with those obtained by HPLC, showing relative standard deviation not exceeding $3.80 \%$.

Jeong et al. (2010) studied the mechanism of oxidation by hydroxyl radicals of four antibiotics from the class of tetracyclines (tetracycline, chlortetracycline, oxytetracycline and doxycycline). The radicals were generated by irradiating the medium with gamma irradiation and pulse radiolysis of electrons which causes the breaking of the water molecule into hydroxyl radicals. They observed that the effectiveness of hydroxyl radical for the four tetracyclines ranged from $32 \%$ to $60 \%$, whereas for aqueous free electrons $\left(\mathrm{e}_{\mathrm{aq}}^{-}\right)$the efficiency was of $15-29 \%$, except for chlortetracycline, which it was $97 \%$.

Rivas et al. (2011) studied the adsorption of doxycycline on charcoal, photolysis with UV-C and ozonation at concentrations of $5 \times 10^{-5} \mathrm{M}$. In the process of adsorption on active carbon they obtained a reduction of 60 to $85 \%$ of TOC but with significant reduction in the efficiency with the reuse; $20 \%$ reduction of the initial concentration for $2 \mathrm{~h}$ photolysis $\mathrm{UV}-\mathrm{C}$, but no reduction of TOC; instantly total degradation of the doxycycline with a $60 \%$ reduction in TOC for the treatment with ozone. The combination of these 3 processes showed a $70 \%$ reduction of TOC.

Yuan et al. (2011) studied the degradation of oxytetracycline, doxycycline and ciprofloxacin with UV radiation and hydrogen peroxide associated with UV in water samples from different origins (ultrapure water, surface water, drinking water and effluent from WWTPs). They evaluated the toxicity of the degradation products by cultures of Vibrio fischer and observed that after treatment with UV no significant reduction in toxicity. For the treatment with $\mathrm{UV} / \mathrm{H}_{2} \mathrm{O}_{2}$ the toxicity initially increased and then decreased forming nontoxic products.

Godos et al. (2012) studied in pilot scale the biosorption and photodegradation of tetracycline in high

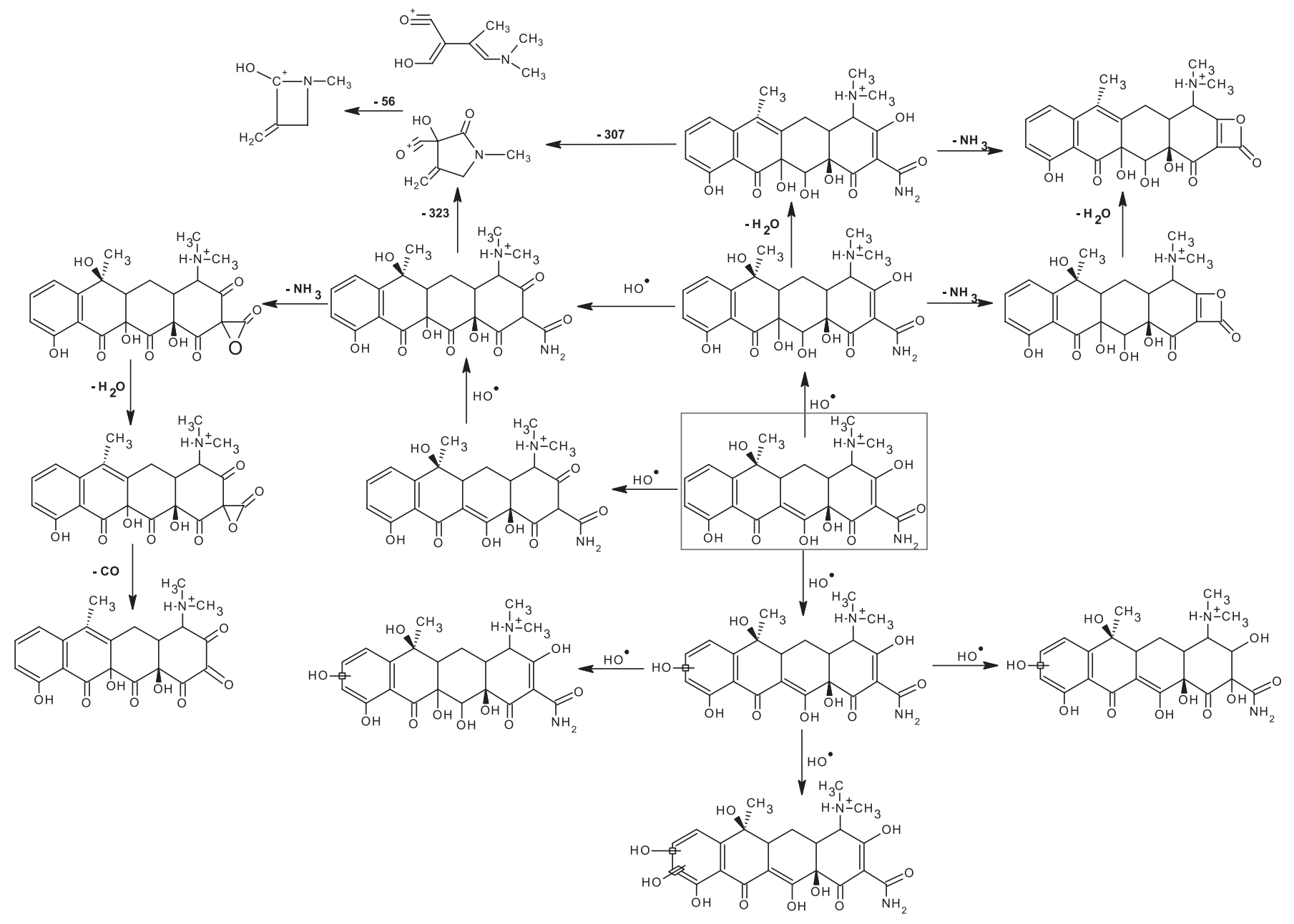

FIGURE 4 - Products of photocatalytic degradation of tetracycline (Adapted from Mboula et al., 2012). 


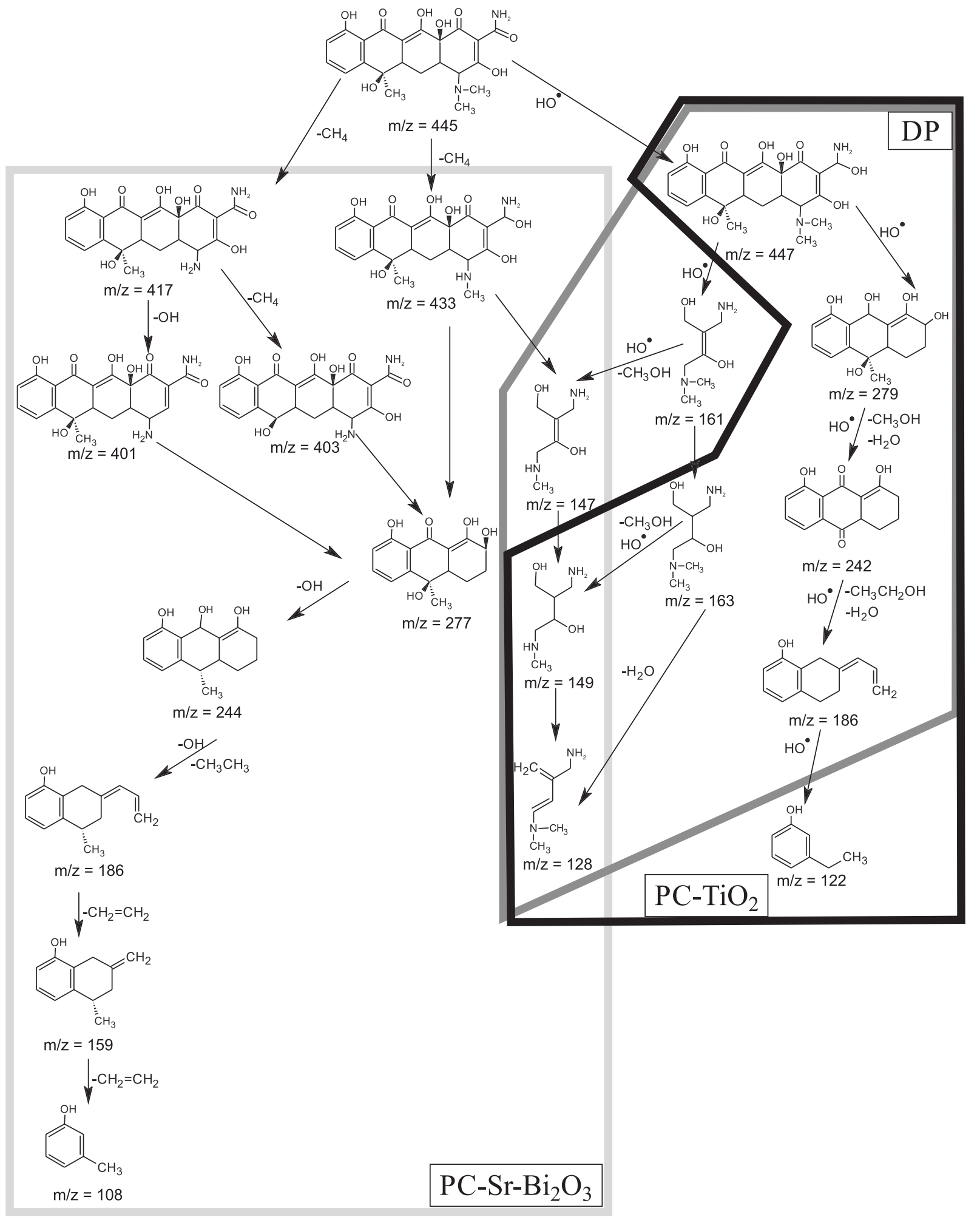

FIGURE 5 - Degradation products of tetracycline through - direct photolysis, - photocatalysis with $\mathrm{TiO}_{2}$ and $\boldsymbol{\sim}$ photocatalysis with $\mathrm{Sr}_{-} \mathrm{Bi}_{2} \mathrm{O}_{3}$ (adapted from Niu et al., 2013).

rate algal ponds (HRAPs) with synthetic sewage from livestock. Those authors found that in HRAPs the process of photodegradation and biosorption of tetracycline are significant and that this type of treatment enables the removal of up to $69 \%$ of tetracycline and its degradation products, depending on the concentration of biomass. 
Mboula et al. (2012) studied the degradation of the tetracycline with a heterogeneous photocatalytic process with $\mathrm{TiO}_{2} / \mathrm{UV}$, focusing on the determination of biodegradability, toxicity and identification of the products formed during the photocatalytic treatment. They observed a $24 \%$ reduction in the concentration of the dissolved organic carbon, and reduced toxicity in Pseudomonas aeruginosa and the non-biodegradability through the Sturm test. The study of the by-products by HPLC-ESI $(+)$ -MS/MS showed that the tetracycline ring is not opened, and thus the structure of the byproducts is not so different from the starting material, as shown in Figure 4.

Niu et al. (2013) studied the photodegradation of tetracycline in aqueous $(5-50 \mathrm{mg} / \mathrm{L})$ for 3 different methods: direct photodegradation, photocatalysis with $\mathrm{TiO}_{2}$ and photocatalysis with $\mathrm{Sr}-\mathrm{Bi}_{2} \mathrm{O}_{3}$. They used as a radiation source a Xenon lamp to simulate solar radiation and with filter that allowed the passage of only the wavelengths of visible light $(\lambda \geq 420 \mathrm{~nm})$. Those authors determined that the photocatalysis with $\mathrm{Sr}_{-} \mathrm{Bi}_{2} \mathrm{O}_{3}$ eliminated $91.2 \%$ of the initial tetracycline, photocatalysis with $\mathrm{TiO}_{2} 80 \%$ and direct photolysis $70 \%$, after 120 minutes run. Based on the analytical results of photodegradation products they proposed some degradation mechanisms of tetracycline, shown in Figure 5.

\section{CONCLUDING REMARKS}

This paper presents multiple aspects that comprise the study of tetracycline, ranging from production, use, chemical reactions, treatment, environmental impact and increasing bacterial resistance. Given the importance of this family of antibiotics in the treatment of various illnesses, their indiscriminate use and the general indifference in the disposal of medicines, studies for elimination and awareness should have greater focus by the scientific community. Little information has been found about the environmental impact of tetracycline; however show alarming situations of bacterial resistance and the presence of these drugs in drinking water.

\section{REFERENCES}

AGA, D.S. (Ed.). Fate of pharmaceuticals in the environment and in water treatment systems. Boca Raton: CRC Press, 2008. 408 p.

ANDREOZZI, R.; RAFFAELE, M.; NICKLAS, P. Pharmaceuticals in STP effluents and their solar photodegradation in aquatic environment. Chemosphere, v.50, p.1319-1330, 2003.
BILA, D.M.; DEZOTTI, M. Fármacos no meio ambiente. Quím. Nova, v.26, p.523-530, 2003.

BOONSANER, M.; HAWKER, D.W. Investigation of the mechanism of uptake and accumulation of zwitterionic tetracyclines by rice (Oryza sativa L.). Ecotoxicol. Environ. Saf., v.78, p.142-147, 2012.

BOXALL, A.B.A.; KOLPIN, D.W.; HALLING-SORENSEN, B.; TOLLS, J. Are veterinary medicines causing environmental risks? Environ. Sci. Technol., v.37, p.286A294A, 2003.

BOXALL, A.B.A. The environmental side effects of medication. EMBO reports, v.5, p.1110-1116, 2004.

COX, L.A.; POPKEN, D.A. Assessing potential human health hazards and benefits from subtherapeutic antibiotics in the United States: tetracyclines as a case study. Risk Anal., v.30, p.432- 457, 2010.

CURI, N.; MARQUES, J.J.; GUILHERME, L.R.G.; LIMA, J.M.; LOPES, A.S.; ALVAREZ, V. Tópicos em ciência do solo. Rev. Bras. Ciênc. Solo, v.3, p.335-400, 2003.

DEPIZZOL, F. Avaliação da resistência a antibióticos em isolados de Escherichia coli provenientes de esgoto hospitalar e sanitário. Vitória-ES, 2006. 145 p. [Dissertation of Master degree. Tecnical Center. Federal University of Espírito Santo].

DÍAZ-CRUZ, M.S.; BARCELÓ, D. Recent advances in LC-MS residue analysis of veterinary medicines in the terrestrial environment. Trends Anal. Chem., v.26, p.637-646, 2007.

ESIOBU, N.; ARMENTS, L.; IKE, J. Antibiotic resistance in soil and water environments. Int. J. Environ. Health Res., v.12, p.133-144, 2002.

FATTA-KASSINOS, D.; VASQUEZ, M.I.; KÜMMERER, $\mathrm{K}$. Transformation products of pharmaceuticals in surface waters and wastewater formed during photolysis and advanced oxidation processes - Degradation, elucidation of byproducts and assessment of their biological potency. Chemosphere, v.85, p.693-709, 2011.

GARTISER, S.; URICH, E.; ALEXY, R.; KUMMERER, K. Anaerobic inhibition and biodegradation of antibiotics in ISO test schemes. Chemosphere, v.66, p.1839-1848, 2007. 
GHOSH, G.C.; OKUDA, T.; YAMASHITA, N.; TANAKA, H. Occurrence and elimination of antibiotics at four sewage treatment plants in Japan and their effects on bacterial ammonia oxidation. Water Sci. Technol., v.59, p.779-786, 2009.

GODOS, I.; MUÑOZ, R.; GUIEYSSEA, B. Tetracycline removal during wastewater treatment in high-rate algal ponds. J. Hazard. Mater., v.229-230, p.446-449, 2012.

GU, G.; KARTHIKEYAN, K.G. Interaction of tetracycline with aluminum and iron hydrous oxides? Environ. Sci. Technol., v.39, p.2660-2667, 2005.

GUJARATHI, N.P.; HANEY, B.J.; LINDEN, J.C. Phytoremediation potential of Myriophyllum aquaticum and Pistia stratiotes to modify antibiotic growth promoters, tetracycline, and oxytetracycline, in aqueous wastewater systems. Int. J. Phytoremedication, v.7, p.99-112, 2005.

HASAN, T.; ALLEN, M.; COOPERMAN, B.S. Anhydrotetracycline is a major product of tetracycline photolysis. J. Org. Chem., v.50, p.1755-1757, 1985.

HELLWEGER, F.L.; RUAN, X.; CHERCHIA, E.; SANCHEZ, S. Applicability of standard antibiotic toxicity testes to the ambient aquatic environment. Ann. Environmental Sci., v.5, p.61-66, 2011.

IKEHATA, K.; NAGHASHKAR, N.J.; EL-DIN, M.G. Degradation of aqueous pharmaceuticals by ozonation and advanced oxidation processes: a review. Ozone-Sci. Eng., v.28, p.353-414, 2006.

JEONG, J.; SONG, W.; COOPER, W.J.; JUNG, J.; GREAVES, J. Degradation of tetracycline antibiotics: mechanisms and kinetic studies for advanced oxidation/reduction processes. Chemosphere, v.78, p.533-540, 2010.

JIA, A.; XIAO, Y.; HU, J.; ASAMI, M.; KUNIKANE, S. Simultaneous determination of tetracyclines and their degradation products in environmental waters by liquid chromatography-electrospray tandem mass spectrometry. J. Chromatogr. A, v.1216, p.4655-4662, 2009.

JIAO, S.; ZHENG, S.; YIN, D.; WANG, L.; CHEN, L. Aqueous photolysis of tetracycline and toxicity of photolytic products to luminescent bacteria. Chemosphere, v.73, p.377-382, 2008
KEMPER, N. Veterinary antibiotics in the aquatic and terrestrial environment. Ecol. Indic., v.8, p.1-13, 2008.

KHAN, S.J.; ONGERTH, J.E. Modelling of pharmaceutical residues in Australian sewage by quantities of use and fugacity calculations. Chemosphere, v.54, p.355-367, 2004.

KHETAN, S.K.; COLLINS, T.J. Human pharmaceuticals in the aquatic environment: a challenge to green chemistry. Chem. Rev., v.107, p.2319-2364, 2007.

KIM, H.Y.; LEE, M.J.; YU, S.H.; KIM, S.D. The individual and population effects of tetracycline on Daphnia magna in multigenerational exposure. Ecotoxicology, v.21, p.9931002, 2012.

KIM, S.D.; CHO, J.; KIM, I.S.; VANDERFORD, B.J.; SNYDER, S.A. Occurrence and removal of pharmaceuticals and endocrine disruptors in South Korean surface, drinking, and waste waters. Water Res., v.41, p.1013-1021, 2007.

KOOLS, S.A.E.; MOLTMANN, J.F.; KNACKER, T. Estimating the use of veterinary medicines in the European Union. Regul. Toxicol. Pharmacol., v.50, p.59-65, 2008.

KUMAR, K.; GUPTA, S.C.; BAIDOO, S.K.; CHANDLER, Y.; ROSEN, C.J. Antibiotic uptake by plants from soil fertilized with animal manure. J. Environ. Qual., v.34, p.2082-2085, 2005.

KUMMERER, K.; AL-AHMAD,A.; MER S C H SUNDERMANN, V. Biodegradability of some antibiotics, elimination of the genotoxicity and affection of wastewater bacteria in a simple test. Chemosphere, v.40, p.701-710, 2000 .

KUMMERER, K. Antibiotics in the aquatic environment: a review. Part I. Chemosphere, v.75, p.417-434, 2009.

MATHERS, J.J.; FLICK, S.C.; COX JR, L.A. Longer-duration uses of tetracyclines and penicillins in U.S. food-producing animals: indications and microbiologic effects - review. Environ. Int., v.37, p.991-1004, 2011.

MBOULA, V.M.; HÉQUET, V.; GRU, Y.; COLIN, R.; ANDRÈS, Y. Assessment of the efficiency of photocatalysis on tetracycline biodegradation. J. Hazard. Mater, p.209210, p.355-364, 2012. 
NIU, J.; DING, S.; ZHANG, L.; ZHAO, J.; FENG, C. Visible-light-mediated $\mathrm{Sr}-\mathrm{Bi}_{2} \mathrm{O}_{3}$ photocatalysis of tetracycline: Kinetics, mechanisms and toxicity assessment. Chemosphere, v.93, p.1-8, 2013.

PEREIRA, L.A.; JARDIM, I.C.S.F.; FOSTIER, A.H.; RATH, S. Ocorrência, comportamento e impactos ambientais provocados pela presença de antimicrobianos veterinários em solo. Quím. Nova, v.35, p.159-169, 2012.

PEREIRA-MAIA, E.C.; SILVA, P.P.; ALMEIDA, W.B.; SANTOS, H.F.; MARCIAL, B.L.; RUGGIERO, R.; GUERRA, W. Tetraciclinas e glicilciclinas: uma visão geral. Quím. Nova, v.33, p.700-706, 2010.

PETROVA, M.; GORLENKO, Z.; MINDLIN, S. Molecular structure and translocation of a multiple antibiotic resistance region of a Psychrobacter psychrophilus permafrost strain. FEMS Microbiol. Lett., v.296, p.190-197, 2009.

PIGNATELLO, J.J.; OLIVEROS, E.; MACKAY, A. Advanced oxidation process for organic contaminant destruction based on the Fenton reaction and related chemistry. Crit. Rev. Env. Sci. Tec., v.36, p.1-84, 2006.

REGITANO, J.B.; LEAL, R.M.P. Comportamento e impacto ambiental de antibióticos usados na produção animal brasileira. Rev. Bras. Ciênc. Solo, v.34, p.601-616, 2010.

REYES, C.; FERNANDEZ, J.; FREER, J.; MONDACA, M.A.; ZAROR, C.; MALATO, S.; MANSILLA, H.D. Degradation and inactivation of tetracycline by $\mathrm{TiO}_{2}$ photocatalysis. J. Photochem. Photobiol. A, v.184, p.141146, 2006.

RIVAS, J.; ENCINAS, A.; BELTRAN, F.; GRAHAN, N. Application of advanced oxidation processes to doxycycline and norfloxacin removal from water. J. Environ. Sci. Health A. Tox. Hazard. Subst. Environ. Eng. A, v.46, p.944-951, 2011.

ROCHA, D.P.; PINTO, G.F.; RUGGIERO, R.; OLIVEIRA, C.A.; GUERRA, W.; FONTES, A.P.S.; TAVARES, T.T.; MARZANO, I.M.; PEREIRA-MAIA, E.C. Coordenação de metais a antibióticos como uma estratégia de combate à resistência bacteriana. Quím. Nova, v.34, p.111-118, 2011.

SARMAH, A.K.; MEYER, M.T.; BOXALL, A.B.A. A global perspective on the use, sales, exposure pathways, ocurrence, fate and effects of veterinary antibiotics (Vas) in the environment. Chemosphere, v.65, p.725-759, 2006.
SASSMAN, S.A.; LEE, L.S. Sorption of three tetracyclines by several soils: assessing the role of $\mathrm{pH}$ and cation exchange. Environ. Sci. Technol., v.39, p.7452-7459, 2005.

SOCIEDADE BRASILEIRA DE PEDIATRIA. Macrolídeos, Glicopeptídeos e tetraciclinas. Available at: $<$ http://www. sbp.com.br/show_item2.cfm?id_categoria=24\&id_ detalhe=667\&tipo_detalhe=S $>$. Accessed on: 03 Aug. 2012.

SUNARIC, S.M.; MITIC, S.S.; MILETIC, G.Z.; PAVLOVIC, A.N.; NASKOVIC-DJOKIC, D. Determination of doxycycline in pharmaceuticals based on its degradation by $\mathrm{Cu}(\mathrm{II}) / \mathrm{H}_{2} \mathrm{O}_{2}$ reagent in aqueous solution. J. Anal. Chem., v.64, p.231-237, 2009.

THIELE-BRUHN, S. Pharmaceutical antibiotic compounds in soils - a review. J. Plant Nutr. Soil Sci., v.166, p.145-167, 2003.

TOLLS, J. Sorption of veterinary pharmaceuticals in soils: a review. Environ. Sci. Technol., v.35, p.3397-3406, 2001.

WATKINSON, A.J.; MURBYD, E.J.; KOLPINE, D.W.; COSTANZO, S.D. The occurrence of antibiotics in an urban watershed: from wastewater to drinking water. Sci. Total Environ., v.407, p.2711-2723, 2009.

WIRTZ, V.J.; DRESER, A.; GONZALES, R. Trends in antibiotic utilization in eight Latin American countries, 1997-2007. Rev. Panam. Salud Pública, v.27, p.219-225, 2010.

WOLLENBERGER, L.; HALLING-SORENSEN, B.; KUSK, K.O. Acute and chronic toxicity of veterinary antibiotics to Daphnia magna. Chemosphere, v.40, p.723-730, 2000.

YANG, W.; TANG, Z.; ZHOU, F.; ZHANG, W.; SONG, L. Toxicity studies of tetracycline on Microcystis aeruginosa and Selenastrum capricornutum. Environ. Toxicol. Pharmacol., v.35, p.320-324, 2013.

YUAN, F.; HU, C.; HU, X.; WEI, D.; CHEN, Y.; QU, J. Photodegradation and toxicity changes of antibiotics in UV and $\mathrm{UV} / \mathrm{H}_{2} \mathrm{O}_{2}$ process. J. Hazard. Mater, v.185, p.12561263,2011 .

ZHAN, M.; YANG, X.; XIAN, Q.; KONG, L. Photosensitized degradation of bisphenol A involving reactive oxygen species in the presence of humic substances. Chemosphere, v.63, p.378-386, 2006. 
ZHANEL, G.G.; HOMENUIK, K.; NICHOL, K.; NOREDDIN, A.; VERCAIGNE, L.; EMBIL, J.; GIN, A.; KARLOWSKY, J.A.; HOBAN, D.J. The glycylcyclines: a comparative review with the tetracyclines. Drugs, v.64, p.63-88, 2004.

ZHANG, Y.; LEJEUNE, J.T. Transduction of bla CMY-2, tet(A), and tet(B) from Salmonella enterica subspecies enteric serovar Heidelberg to S.Typhimurium. Vet. Microbiol., v.129, p.418-425, 2007.
ZHAO, Y.; GENG, J.; WANG, X.; GU, X.; GAO, S. Adsorption of tetracycline onto goethite in the presence of metal cations and humic substances. J. Colloid Interface Sci., v.361, p.247-251, 2011a.

ZHAO, Y.; GENG, J.; WANG, X.; GU, X.; GAO, S. Tetracycline adsorption on kaolinite: $\mathrm{pH}$, metal cations and humic acid effects. Ecotoxicology, v.20, p.1141-1147, 2011b.

Received for publication on $01^{\text {st }}$ November 2012 Accepted for publication on $14^{\text {th }}$ November 2013 